\title{
DEGRADASI ZAT WARNA AZO TARTRAZIN PADA LIMBAH CAIR MIE DENGAN METODE AOPs (Advanced Oxidation Processes)
}

\author{
Tien Setyaningtyas* dan Dian Windy Dwiasi \\ Program studi Kimia, Jurusan MIPA, Fakultas Sains dan Teknik, \\ Universitas Jenderal Soedirman Purwokerto \\ Email : tien_kimia@yahoo.co.id
}

\begin{abstract}
ABSTRAK
Penggunaan metode untuk mendegradasi zat warna dari limbah industri dengan proses AOPs (Advanced Oxidation Processes) atau proses oksidasi lanjut saat ini banyak dikembangkan terutama untuk limbah cair zat warna yang sulit terdegradasi. Salah satu industri makanan yang menggunakan bahan aditif zat warna pada proses produksinya adalah industri mie yaitu menggunakan zat warna tartrazin. Dampak negatif perkembangan industri mie adalah timbulnya pencemaran lingkungan dari limbah cair industri mie yang masih mengandung zat warna tartrazin. Penurunan kadar zat warna tartrazin dalam limbah cair mie dapat diupayakan dengan cara mendegradasi zat warna tartrazin melalui metode AOPs.

Proses AOPs untuk mendegradasi tartrazin dalam limbah cair mie pada penelitan ini menggunakan kombinasi $\mathrm{H}_{2} \mathrm{O}_{2}$ dengan sinar matahari sebagai sumber sinar UV $\left(\mathrm{H}_{2} \mathrm{O}_{2} / \mathrm{UV}\right.$-Vis). Paramaeter yang dilakukan antara lain variasi konsentrasi $\mathrm{H}_{2} \mathrm{O}_{2}$ yaitu 0,01 $\mathrm{M} ; 0,02 \mathrm{M}$ dan $0,03 \mathrm{M}$ dengan variasi waktu kontak $0 ; 0,5 ; 1 ; 1,5 ; 2 ; 2,5 ; 3 ; 3,5 ; 4$ jam. Pengaruh $\mathrm{pH}$ terhadap degradasi tartrazin dengan variasi 2, 5, 7, 9 dan 12.

Hasil yang diperoleh bahwa degradasi tartrazin tidak dipengaruhi oleh konsentrasi $\mathrm{H}_{2} \mathrm{O}_{2}$ tetapi konsentrasi $\mathrm{H}_{2} \mathrm{O}_{2}$ mempengaruhi waktu kesetimbangan. Waktu kesetimbangan paling cepat dicapai 30 menit pada konsentrasi $\mathrm{H}_{2} \mathrm{O}_{2} 0,03 \mathrm{M}$, sedangkan untuk $\mathrm{H}_{2} \mathrm{O}_{2}$ 0,01M dan 0,02 $\mathrm{M}$ waktu kesetimbangan tercapai pada 2,5 jam dengan penurunan tartrazin sebesar $45 \%$. Proses AOPs pada degradasi tartrazin dipengaruhi oleh harga $\mathrm{pH}$. Pada $\mathrm{pH}$ rendah penurunan tartrazin semakin besar. Pernurunan tartrazin paling besar pada $\mathrm{pH} 2$ yaitu sebesar $65 \%$.
\end{abstract}

Kata kunci : zat warna tartrazin, degradasi, AOPs, $\mathrm{H}_{2} \mathrm{O}_{2} / \mathrm{UV}-\mathrm{Vis}$ (Sinar Matahari)

\section{DEGRADATION OF AZO DYE TARTRAZINE IN INDUSTRIAL WASTEWATER OF NOODLES WITH AOPs (Advanced Oxidation Processes) METHOD}

\begin{abstract}
The use of Advanced Oxidation Processes (AOPs) to degrade the dyes from industrial wastewater is currently developing. One of the industries that use food dye additives in the production process is noodle industry using dye tartrazine. The use of tartrazine as an additive on noodle industry may endanger the environment. The degradation of tartrazine dye from noodles industrial wastewater can be pursued using AOPs methods
\end{abstract}


The AOPs process to degrade wastewater tartrazine noodles in this research uses a combination of $\mathrm{H}_{2} \mathrm{O}_{2}$ with sunlight as a source of UV light $\left(\mathrm{H}_{2} \mathrm{O}_{2} / \mathrm{UV}\right.$-Vis). Parameter variations that carried out, are the concentration of $\mathrm{H}_{2} \mathrm{O}_{2}$ is $0.01 \mathrm{M}: 0.02 \mathrm{M}$ and $0.03 \mathrm{M}$ with a contact time variation of $0,0.5,1,1.5,2,2.5 ; 3 ; 3.5$; and 4 hours. Effect of $\mathrm{pH}$ on the degradation was also and carried out with variation $\mathrm{pH} 2,5,7,9$ and 12 .

The results obtained tartrazine that degradation is not affected by $\mathrm{H}_{2} \mathrm{O}_{2}$ concentration but the concentration of $\mathrm{H}_{2} \mathrm{O}_{2}$ affects the equilibrium time. When equilibrium is most quickly achieved at 30 minutes at a concentration of $0.03 \mathrm{M} \mathrm{H}_{2} \mathrm{O}_{2}$, while for $\mathrm{H}_{2} \mathrm{O}_{2} 0.01 \mathrm{M}$ and $0.02 \mathrm{M}$ the equilibrium is reached at 2.5 hours with a decrease of $45 \%$ of tartrazine. AOPs on the degradation process of tartrazine is influenced by $\mathrm{pH}$. At low $\mathrm{pH}$ the greater the reduction tartrazine. The greatest degradation was at $\mathrm{pH} 2$ with $65 \%$ lost of tartrazine. .

Key words : tartrazine, degradation, AOPs, $\mathrm{H}_{2} \mathrm{O}_{2} / \mathrm{UV}-\mathrm{Vis}$ (sunlight)

\section{PENDALUHUAN}

Permasalahan lingkungan saat ini yang dominan salah satunya adalah limbah cair yang berasal dari industri. Limbah cair yang tidak dikelola akan menimbulkan dampak yang luar biasa pada perairan, khususnya sumber daya air. Kelangkaan sumber daya air di masa mendatang dan bencana alam semisal erosi, banjir, dan kepunahan ekosistem perairan tidak pelak lagi dapat terjadi apabila permasalahan tersebut tidak diperhatikan dari sekarang. Permasalahan air bersih sebenarnya ada pada pembuangan limbah cair yang dilakukan secara sembarangan dari hasil kegiatan industri serta limbah domestik perkotaan. Ditambah lagi dengan kurangnya usaha untuk mengolah limbah cair secara benar.

Perkembangan industri di Indonesia saat ini cukup pesat seiring dengan semakin majunya ilmu pengetahuan dan teknologi. Kondisi tersebut memberikan manfaat yang besar bagi kesejahteraan masyarakat. Selain dapat memberikan dampak positif bagi kehidupan manusia, perkembangan industri juga dapat menimbulkan masalah bagi lingkungan seperti limbah industri. Limbah industri yang langsung dibuang ke lingkungan tanpa adanya pengolahan terlebih dahulu dapat membahayakan kehidupan ekosistem lingkungan
(Ahmad, 2004). Industri yang mempunyai kontribusi menimbulkan pencemaran lingkungan misalnya industri yang menggunakan bahan aditif zat warna pada proses produksinya. Antara lain industri batik, cat, dan industri makanan. Salah satu industri makanan yang menggunakan bahan aditif zat warna adalah industri mie.

Industri mie saat ini mulai berkembang di Indonesia, namun kemajuan dibidang industri ini tidak diiringi dengan kesadaran yang memadai dalam pengolahan limbah. Limbah cair industri mie pada umumnya mengandung zat warna. Salah satu zat warna yang digunakan dalam proses produksi adalah zat warna tartrazin yang merupakan pewarna sintetis. Pembuangan limbah cair secara langsung ke lingkungan dapat berdampak pada rusaknya ekosistem. Oleh karena itu sebelum dibuang ke lingkungan limbah cair mie perlu diolah terlebih dahulu (Azuan et al, 2001).

Pengolahan limbah dapat dibagi menjadi pengolahan primer, pengolahan sekunder, dan pengolahan tersier. Pengolahan primer (pengolahan secara fisika) biasanya dilakukan dengan koagulasi, flokulasi atau penyaringan, sedangkan pada pengolahan sekunder (pengolahan secara biologi), limbah 
diuraikan dengan bantuan mikroorganisme. Limbah yang bersifat tidak dapat diuraikan secara biologi (nonbiodegradable), diolah dengan pengolahan tersier. Beberapa contoh limbah nonbiodegradable adalah limbah pewarna, pestisida, herbisida, organik klor (Clesceri et al, 1998). Umumnya pengolahan fisika-kimia seperti koagulasi, adsorpsi dengan karbon aktif, dan ultrafiltrasi dapat menghilangkan zat warna dengan efekti, akan tetapi, prosesproses tersebut bersifat non destruktif, karena hanya memindahkan zat warna dari limbah cair ke media padat yang memerlukan penanganan lebih lanjut (Azuan et al, 2001).

Berbagai upaya dan metode untuk mengatasi pencemaran zat warna sebelum dibuang ke perairan telah dilakukan, antara lain metode koagulasi, oksidasi dan elektrokimia. Namun metode ini dirasa kurang memadai untuk mengatasi masalah pencemaran zat warna, karena metode ini pada dasarnya hanya menghasilkan keadaan yang mengandung polutan yang lebih terkonsentrasi. Beberapa metode modern seperti metode biodegradasi, klorinasi, dan ozonisasi telah dikembangkan. Metode ini memang memberikan hasil yang cukup memuaskan, tetapi membutuhkan biaya operasional yang cukup mahal sehingga kurang efektif diterapkan di Indonesia. Di antara metode modern penanggulangan limbah, adalah metode degradasi dengan proses AOPs yang merupakan metode alternatif yang sederhana, cepat, efisien dan murah. Menurut Munter (2001) metode Advanced oxidation process $(A O P s)$, memiliki kelebihan utama yaitu dapat mendegradasi/ menguraikan secara tuntas senyawa-senyawa berbahaya yang bersifat nonbiodegradable dalam limbah melalui proses oksidasi (oxidative degradation).

Saat ini penggunaan teknologi oksidasi atau lebih dikenal dengan nama
Advanced Oxidation Processes (AOPs) mendapat perhatian cukup besar, karena teknologi ini dapat menguraikan serta membersihkan senyawa-senyawa organik yang selama ini sulit atau tidak dapat diuraikan dengan metode mikrobiologi atau membran filtrasi. Selain itu, teknologi ini dapat diaplikasikan tidak hanya untuk mengolah limbah cair hasil industri, namun dapat juga dipergunakan untuk mengolah air minum atau air bersih (Mohajerani et al, 2004).

Teknologi AOPs adalah satu atau kombinasi dari beberapa proses seperti ozon, hidrogen peroksida, sinar UV, titanium oksida, fotakatalis serta beberapa proses lainnya untuk menghasilkan radikal bebas $\bullet \mathrm{OH}$. Radikal bebas $\bullet \mathrm{OH}$ adalah spesies aktif yang dikenal memiliki oksidasi potensial tinggi 2,8 V melebihi ozon yang memiliki oksidasi potensial hanya 2,07 V. Hal ini membuat radikal bebas $\bullet \mathrm{OH}$ sangat mudah mengoksidasi senyawa-senyawa organik maupun non organik (Pesoutova et al, 2011).

Metode kombinasi dari hidrogen peroksida, dan sinar UV merupakan metode yang paling banyak diteliti serta dicoba untuk mengolah berbagai jenis limbah cair. Diikuti selanjutnya dengan metode titanium oksida dan reaksi fenton. Lifetime dari $\bullet \mathrm{OH}$ tergantung dari konsentrasinya. Sebagai contoh, untuk -OH berkonsentrasi $1 \mu \mathrm{M}$, lifetime-nya adalah sekitar $200 \mu \mathrm{s}$. Kecepatan reaksi -OH dengan senyawa organik atau nonorganik adalah sekitar 107 1.010 $\mathrm{M}^{-1} \mathrm{~s}^{-1}$. ( Nugroho dan Ikbal, 2005)

Hidrogen peroksida $\left(\mathrm{H}_{2} \mathrm{O}_{2}\right)$ merupakan suatu bahan pengoksida sangat kuat yang mampu menghancurkan beberapa campuran yang bersifat garam dan bukan garam di dalam media yang mengandung air. Sinar UV dengan sendirinya juga mampu menurunkan dengan memicu perpecahan ikatan. Kombinasi perlakuan keduanya, hidrogen 
peroksida dan UV dapat menciptakan suatu proses efisien dan yang sangat cepat untuk penyelesaian permasalahan zat-zat pencemar. Sinar UV yang digunakan dapat berasal dari lampu UV maupun sinar matahari (Kito et al, 1998). Indonesia merupakan negara tropis yang kaya akan sinar matehari.

Berdasarkan hal tersebut maka dalam penelitian ini menerapkan proses oksidasi lanjut yang menggunakan kombinasi hidrogen peroksida dengan sinar matahari sebagai sumber sinar UV untuk mendegradasi zat warna tartrazin limbah cair industri mie.

\section{METODE PENELITIAN}

\section{Alat dan Bahan}

Alat-alat yang digunakan dalam penelitian adalah pengaduk magnet, spektrofotometer UV-Vis Shimadzu (UV-1601), kertas saring, stopwatch, pH meter dan alat-alat gelas.

Bahan-bahan yang digunakan dalam penelitian ini adalah limbah cair industri pembuatan mie kuning (industri rumah tangga di daerah Karangpucung Cilacap), tartrazin, akuademineral, $\mathrm{H}_{2} \mathrm{O}_{2}$, dan larutan buffer $\mathrm{pH}$ 2, 5, 7, 9,12

\section{Prosedur Penelitian}

\section{Preparasi sampel}

Limbah cair mie yang mengandung tartrazin diperoleh dari daerah Cilacap dengan menggunakan jerigen plastik dan diukur $\mathrm{pH}$ dan konsentrasi tartrazinnya.

\section{Penentuan panjang gelombang maksimum tartrazin}

Sebanyak $10 \mathrm{~mL}$ larutan induk tartrazin dengan konsentrasi 500 ppm diencerkan dengan akuademineral sampai $100 \mathrm{~mL}$. Larutan tersebut kemudian diambil $10 \mathrm{~mL}$ dan diencerkan dengan akuademin sampai $100 \mathrm{~mL}$. Larutan diukur absorbansinya dengan spektrofotometer UV-Vis pada panjang gelombang $420 \mathrm{~nm}$ sampai $450 \mathrm{~nm}$. Panjang gelombang maksimum diperoleh pada absorbansi maksimum.

\section{Pembuatan kurva kalibrasi}

Larutan standar tartrazin dengan konsentrasi $0,1,5,10,15$ dan $20 \mathrm{ppm}$ masing-masing. Setelah itu, diukur absorbansinya dengan spektrofotometer UV-Vis pada panjang gelombang maksimum, kemudian dibuat kurva standarnya (konsentrasi versus absorbansi).

\section{Degradasi Tartrazin dengan $\mathrm{H}_{2} \mathrm{O}_{2}$}

\section{Pengaruh Waktu kontak dan konsentrasi $\mathrm{H}_{2} \mathrm{O}_{2}$}

Kedalam 3 buah gelas piala dimasukkan sampel limbah cair mie masing-masing sebanyak $500 \mathrm{~mL}$. Kemudian ditambahkan $\mathrm{H}_{2} \mathrm{O}_{2}$ masingmasing dengan konsentrasi $0,01 \mathrm{M}, 0,02$ M, dan 0,03 M. Setelah itu ditempatkan di daerah yang terkena sinar matahari dan diaduk dengan magnetic stirer. Setiap selang waktu 30 menit, diambil sebanyak $20 \mathrm{~mL}$ kemudian tartazin yang tersisa diukur absorbansinya menggunakan spektofotometer UV-Vis pada panjang gelombang maksimum. Absorbansi yang terukur diplotkan ke kurva kalibrasi untuk mengetahui konsentrasi tartrazin. Selisih antara tartrazin awal sebelum perlakuan dengan tartrazin setelah perlakuan merupakan banyaknya tartrazin yang terdegradasi. Waktu penyinaran dilakukan pada jam 9.00 sampai 13.00. Lama waktu penyinaran optimum terjadi pada penurunan tartrazin yang paling besar. Waktu optimum ini digunakan untuk perlakukan selanjutnya.

\section{Pengaruh pH}

Limbah cair mie dilakukan variasi pH menjadi 2, 5, 7, 9 dan 12. Untuk 
mencapai $\mathrm{pH}$ yang diinginkan, dilakukan penambahan buffer sesuai $\mathrm{pH}$ yang didinginkan. Nilai $\mathrm{pH}$ diukur dengan menggunakan $\mathrm{pH}$ meter. Setelah $\mathrm{pH}$ limbah sesuai dengan yang diinginkan, kemudian ditambah $\mathrm{H}_{2} \mathrm{O}_{2}$ dengan konsentrasi $0,01 \quad$ M. Kemudian ditempatkan di daerah yang terkena sinar matahari secara langsung dan diaduk dengan magnetic stirer selama waktu kontak optimum Setelah itu diambil 20 $\mathrm{mL}$ dan larutan diukur absorbansinya dengan spektrofotometer UV-Vis pada panjang gelombang maksimum. Hal tersebut diperlakukan juga untuk konsentrasi $\mathrm{H}_{2} \mathrm{O}_{2}$ 0,02 $\mathrm{M}$ dan $0,03 \mathrm{M}$

\section{Penentuan Persen Penurunan}

Persen penurunan konsentrasi tartrazin dihitung dari perumusan :

$\%$ Penurunan : $\frac{C_{a w a l}-C_{a k h i r}}{C_{a w a l}} \times 100 \%$

Dengan $\mathrm{C}_{\mathrm{awal}}$ adalah konsentrasi tartrazin mula-mula, sedangkan $\mathrm{C}_{\text {akhir }}$ adalah konsentrasi tartrazin setelah degradasi.

\section{HASIL DAN PEMBAHASAN}

Pengelolaan limbah cair dalam proses produksi dimaksudkan untuk meminimalkan limbah yang terjadi, volume limbah minimal dengan konsentrasi dan toksisitas yang juga minimal. Sedangkan pengelolaan limbah cair setelah proses produksi dimaksudkan untuk menghilangkan atau menurunkan kadar bahan pencemar yang terkandung didalamnya sehingga limbah cair tersebut memenuhi syarat untuk dapat dibuang. Dengan demikian dalam pengolahan limbah cair untuk mendapatkan hasil yang efektif dan efisien perlu dilakukan langkah-langkah pengelolaan yang dilaksanakan secara terpadu dengan dimulai dengan upaya minimisasi limbah (waste minimization), pengolahan limbah (waste treatment), hingga pembuangan limbah produksi (disposal) (Luthfi, 2004).

Salah satu alternatif teknologi pengolahan limbah adalah dengan Advanced Oxidation Processes (AOPs). Pada penelitian ini proses AOPs merupakan proses reaksi oksidasi secara kimiawi yang menggunakan hidrogen peroksida $\left(\mathrm{H}_{2} \mathrm{O}_{2}\right)$ sebagai oksidator yang menghasilkan radikal bebas dengan sinar matahari sebagai sumber sinar UV. Penggunaannya $\mathrm{H}_{2} \mathrm{O}_{2} \quad$ mempunyai keuntungan, yaitu: aman, selektif, kuat dan mudah diperoleh. Pada umumnya, beberapa parameter AOPs yang biasa berpengaruh terhadap hasil pengolahan limbah diantaranya $\mathrm{pH}$ dan waktu kontak (Muruganandham and Swaminathan, 2006).

Keunggulan metode AOPs antara lain (1) mampu mendegradasi polutan organik yang tidak terdegradasi dengan proses konvensional, (2) Dapat mereduksi zat warna yang tidak bisa diuraikan dengan teknologi lain, (3) Tidak menghasilkan sludge yang harus diolah lagi seperti pada teknologi koagulasi/sedimentasi (4) Tidak memerlukan proses regenerasi atau proses pencucian seperti pada pemakaian absorbent atau membran penyaring (Chaudhuri and Wei. 2009 ). Pada penelitian ini proses AOPs menggunakan $\mathrm{H}_{2} \mathrm{O}_{2} / \mathrm{UV}$-Vis sinar matahari diterapkan untuk mendegradasi zat warna tartrazin pada limbah cair mie.

Tartrazin yang merupakan salah satu zat warna sintetis,pembuatan zat warna ini biasanya melalui perlakuan pemberian asam sulfat atau asam nitrat yang sering kali terkontaminasi oleh arsen atau logam berat lain yang bersifat racun (Moutinho et al, 2007). Struktur Tartrazin $\left(\mathrm{C}_{16} \mathrm{H}_{12} \mathrm{~N}_{4} \mathrm{Na}_{3} \mathrm{O}_{9} \mathrm{~S}_{2}\right)$ terlihat pada Gambar 1 dibawah ini: 
<smiles>O=[N+]([O-])c1ccc(/N=N/c2c([N+](=O)[O-])nn(-c3ccc(S(=O)(=O)[O-])cc3)c2O)cc1</smiles>

Gambar 1. Struktur Tartrazin (Shahrour et al, 2008)

\section{Penentuan Panjang gelombang maksimum}

Penentuan panjang gelombang maksimum $\left(\lambda_{\text {maks }}\right)$ diperlukan untuk menetapkan serapan maksimum terhadap sinar pada $\lambda$ tertentu. Perbedaan tingkat energi antar orbital molekul merupakan panjang gelombang serapan molekul. Setiap molekul memiliki panjang gelombang yang berbeda tergantung dari bentuk strukturnya dan sifat dasar molekul dalam larutan (Hendayana dkk, 1994)

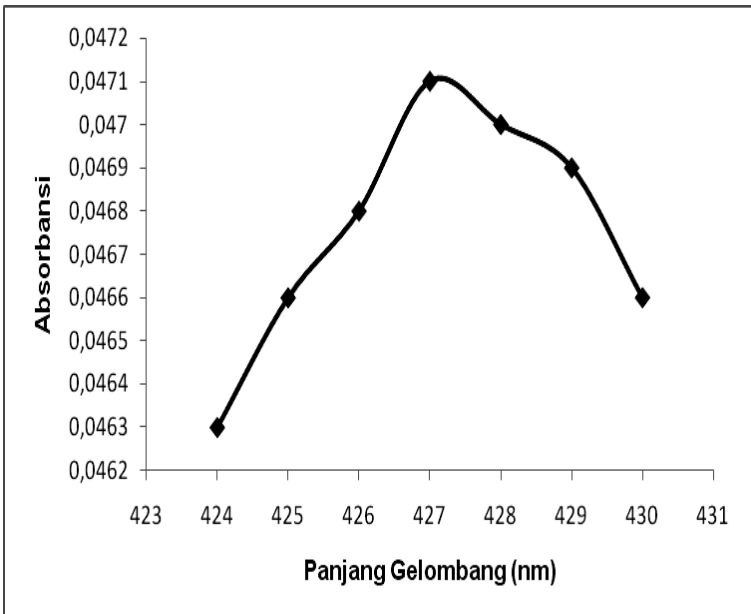

Gambar 2. Kurva penentuan panjang gelombang maksimum larutan tartrazin

Panjang gelombang maksimum $\left(\lambda_{\text {maks }}\right)$ diperoleh dengan melihat absorbansi yang paling besar dari larutan yang diukur pada range panjang gelombang antara 420-450 nm. Hasil penelitian menunjukkan $\lambda_{\text {maks }}$ tartrazin yaitu $427 \mathrm{~nm}$ dengan absorbansi 0,0471 dan masih dalam range panjang gelombang warna larutan yang berwarna hijau kekuningankuning yaitu 400-460 nm (Hendayana dkk, 1994). Penentuan panjang gelombang maksimum $\left(\lambda_{\text {maks }}\right)$ terlihat pada Gambar 2.

\section{Kurva Kalibrasi}

Kurva kalibrasi tartrazin adalah kurva absorbansi terhadap variasi konsentrasi larutan tartrazin. Pembuatan kurva kalibrasi larutan standar tartrazin yaitu dengan cara mengukur nilai absorbansi larutan tartrazin pada panjang gelombang maksimum $427 \mathrm{~nm}$ dengan variasi konsentrasi. Dari pengukuran absorbansi larutan tartrazin yang mempunyai konsentrasi $0,1,5,10,15$ dan $20 \mathrm{mg} / \mathrm{L}$ (ppm), didapat kurva kalibrasi yang mempunyai persamaan garis lurus $\mathrm{y}=0,010 \mathrm{x}-0,002$ dengan $\mathrm{R}^{2}$ $=0,998 ;$ dengan sumbu $\mathrm{y}$ adalah absorbansi dan sumbu $\mathrm{x}$ adalah konsentrasi tartrazin $(\mathrm{mg} / \mathrm{L})$. Kurva kalibrasi ditunjukkan pada Gambar 3.

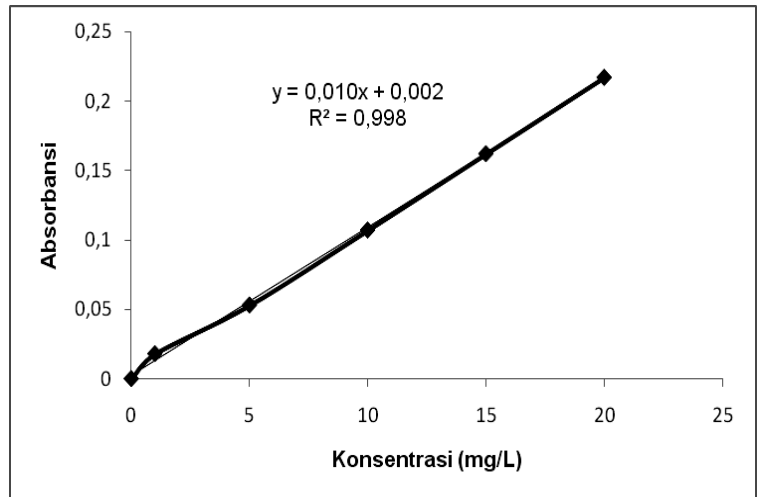

Gambar 3. Kurva kalibrasi larutan standar Tartrazin

Sampel awal limbah cair mie pada waktu yang bersamaan diukur absorbansinya, dan dari hasil pengukuran diperoleh absorbansi sampel sebesar 0,181. Konsentrasi awal sampel dihitung dengan memplotkan atau memasukkan absorbansi ke dalam kurva kalibrasi dan dari hasil perhitungan diperoleh konsentrasi sampel sebesar 17,912 ppm dengan harga $\mathrm{pH}$ air limbah mie sekitar 5. 


\section{Pengaruh Waktu kontak dan konsentrasi $\mathrm{H}_{2} \mathrm{O}_{2}$}

Mekanisme reaksi yang terjadi pada sistem $\mathrm{H}_{2} \mathrm{O}_{2} / \mathrm{UV}$ adalah pemecahan molekul $\mathrm{H}_{2} \mathrm{O}_{2}$ ketika terpapar sinar UV menjadi 2 molekul radikal $\bullet \mathrm{OH}$. Hal ini dapat meningkatan proses fotodegradasi (Mahamuni and Adewuyi, 2010). Proses AOPs ini terjadi dikarenakan $\mathrm{H}_{2} \mathrm{O}_{2}$ merupakan oksidator yang dapat menghasilkan radikal $\bullet \mathrm{OH}$ untuk mengoksidasi senyawa-senyawa organik sedangkan sinar UV dapat juga digunakan untuk mendegradasi senyawasenyawa organik, sehingga terjadi proses lanjutan dari oksidasi (Preis et al., 2000). Variasi konsentrasi $\mathrm{H}_{2} \mathrm{O}_{2}$ dilakukan untuk mengetahui pengaruh konsentrasi dalam mendegradasi tartrazin dalam limbah cair industri mie. Variasi konsentrasi $\mathrm{H}_{2} \mathrm{O}_{2}$ yang digunakan dalam penelitian ini adalah 0,01 $\mathrm{M} ; 0,02 \mathrm{M}$, dan 0,03 $\mathrm{M}$. Hasil yang diperoleh dari pengaruh konsentrasi $\mathrm{H}_{2} \mathrm{O}_{2}$ dan waktu kontak dapat dilihat pada Gambar 4.

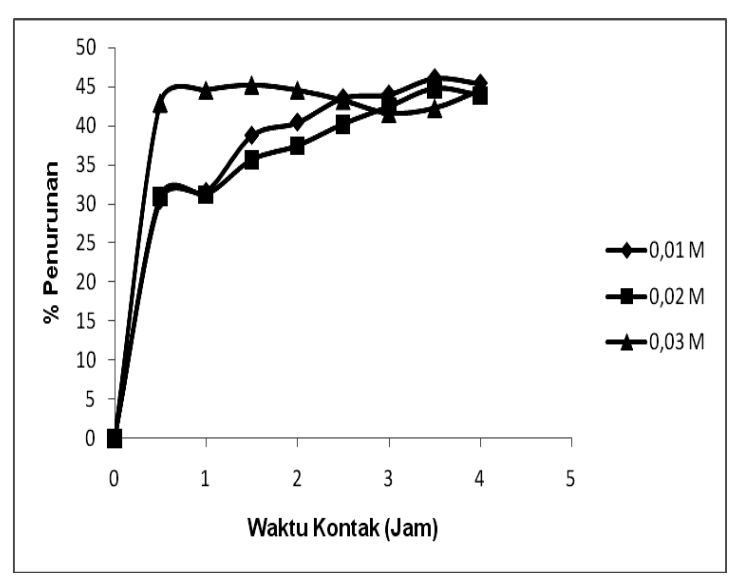

Gambar 4. Pengaruh waktu kontak terhadap persen penurunan zat warna tartrazin dalam limbah cair mie

Pada Gambar 4 terlihat hasil pengaruh konsentasi $\mathrm{H}_{2} \mathrm{O}_{2}$ terhadap degradasi tartrazin dengan variasi waktu kontak. Hasil yang diperoleh, degradasi tartrazin tidak dipengaruhi oleh konsentrasi $\mathrm{H}_{2} \mathrm{O}_{2}$ tetapi konsentarsi $\mathrm{H}_{2} \mathrm{O}_{2}$ mempengaruhi waktu kesetimbangan. Semakin besar konsentrasi $\mathrm{H}_{2} \mathrm{O}_{2}$ maka waktu kesetimbangan akan semakin cepat tercapai. Pada penelitian ini waktu kesetimbangan tercepat pada konsentrasi $\mathrm{H}_{2} \mathrm{O}_{2}$ 0,03 $\mathrm{M}$ dengan waktu 30 menit sedangkan untuk konsentrasi 0,02 $\mathrm{M}$ dan 0,01 M waktu kesetimbangan tercapai pada 2,5 jam. Perpanjangan waktu kontak tidak menampah penurunan tartrazin. Hasil yang diperoleh penurunan tartrazin adalah sebesar $45 \%$ untuk konsentrasi $\mathrm{H} 2 \mathrm{O} 20,01 \mathrm{M}, 0,02 \mathrm{M}$ dan 0,03 $\mathrm{M}$. Degradasi tartrazin terjadi disebabkan radikal $\bullet \mathrm{OH}$ yang mampu mengoksidasi zat tersebut. Menurut Muruganandham dan Swaminathan (2006) mekanisme pembentukan radikal $\bullet \mathrm{OH}$ dari $\mathrm{H}_{2} \mathrm{O}_{2} / \mathrm{UV}$ adalah sebagai berikut :

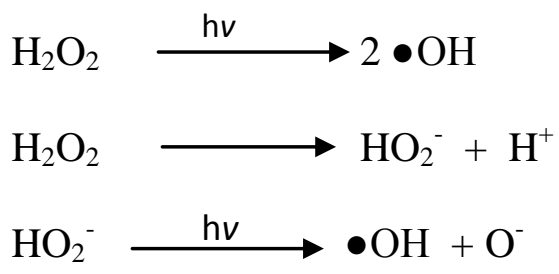

Mekanisme degradasi senyawa organik oleh radikal $\bullet \mathrm{OH}$ adalah sebagai berikut : (Rohmah dan Sugiarto, 2008)

$$
\begin{aligned}
& \mathrm{RH}+\bullet \mathrm{OH} \rightarrow \mathrm{H}_{2} \mathrm{O}+\bullet \mathrm{R} \\
& 2 \bullet \mathrm{OH} \rightarrow \mathrm{H}_{2} \mathrm{O}_{2} \\
& \bullet \mathrm{R}+\mathrm{H}_{2} \mathrm{O}_{2} \rightarrow \mathrm{ROH}+\bullet \mathrm{OH} \\
& \bullet \mathrm{R}+\mathrm{O}_{2} \rightarrow \mathrm{ROO} \bullet \\
& \mathrm{ROO} \bullet+\mathrm{RH} \rightarrow \mathrm{ROOH}+\mathrm{R} \bullet
\end{aligned}
$$

\section{Pengaruh pH terhadap degradasi tartrazin}

Pengaruh $\mathrm{pH}$ limbah cair industri mie terhadap aktivitas $\mathrm{H}_{2} \mathrm{O}_{2}$ dapat dilihat dari penurunan kadar tartrazin dalam limbah cair mie yang dikondisikan dalam $\mathrm{pH} 2$, $5,7,9$, dan 12 oleh $\mathrm{H}_{2} \mathrm{O}_{2}$. Pengaruh $\mathrm{pH}$ limbah mie terhadap aktivitas $\mathrm{H}_{2} \mathrm{O}_{2}$ dapat dilihat pada Gambar 5. 
Pada Gambar 5 terlihat pengaruh $\mathrm{pH}$ terhadap degradasi tartrazin. Hasil yang diperoleh bawah $\mathrm{pH}$ semakin rendah degradasi tartrazin menggunkan $\mathrm{H}_{2} \mathrm{O}_{2} /$ sinar matahari akan semakin tinggi. Pada $\mathrm{pH} 2$ degradasi tartrazin untuk konsentrasi $\mathrm{H}_{2} \mathrm{O}_{2} \quad 0,01 \mathrm{M}, 0,02 \mathrm{M}$, dan $0,03 \mathrm{M}$ sekitar $65 \%$, sedangkan yang paling rendah adalah pada $\mathrm{pH} 12$ yaitu sekitar 10\%. Menurut Rohmah dan Sugiarto (2008) pada kondisi asam, hidrogen peroksida sangat stabil, pada kondisi basa mudah terurai.

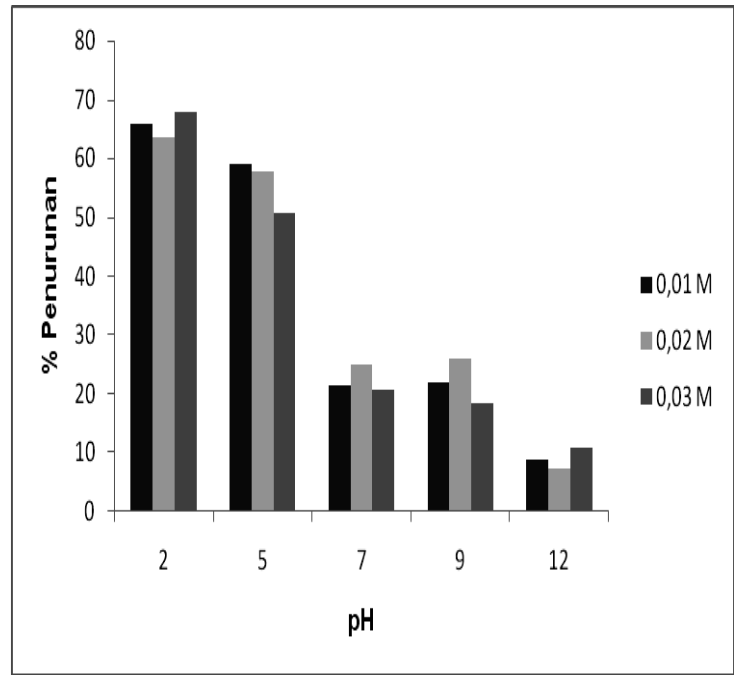

Gambar 5. Pengaruh $\mathrm{pH}$ terhadap persen penurunan tartrazin

Pada suasana asam, radikal hidroksil yang dihasilkan oleh sistem fotokatalis akan meningkat karena semakin melimpahnya $\mathrm{H}^{+}$. Selain itu, menurut Pesoutova et. al (2011) pembentukan radikal bebas $\cdot \mathrm{OH}$ yang sebagian besar berasal dari $\mathrm{H}_{2} \mathrm{O}_{2}$ tidak disukai pada dekomposisi senyawa organik pada $\mathrm{pH}$ tinggi, sehingga $\cdot \mathrm{OH}$ yang dihasilkan lebih sedikit. Menurut Hudaya dkk (2010) $\mathrm{H}_{2} \mathrm{O}_{2}$ pada suasana asam dapat memicu terbentuknya lebih banyak radikal $\bullet \mathrm{OH}$ lewat pembentukan $\mathrm{H}_{2} \mathrm{O}_{2}$ hasil reaksi $\bullet \mathrm{O}_{2}^{-}$dengan ion Hidrogen $\left(\mathrm{H}^{+}\right)$. Spesies $\bullet \mathrm{O}_{2}^{-}$merupakan hasil reaksi antara $\mathrm{O}_{2}$ dengan sebuah elektron bebas (hasil eksitasi elektron dari molekul organik akibat radiasi UV).
Reaksi pembentukan radikal $\bullet \mathrm{OH}$ tersebut mengikuti mekanisme sebagai berikut:

$$
\begin{aligned}
& \bullet \mathrm{O}_{2}^{-}+\mathrm{H}^{+} \rightarrow \bullet \mathrm{HO}_{2} \\
& 2 \bullet \mathrm{HO}_{2} \rightarrow \mathrm{H}_{2} \mathrm{O}_{2}+\mathrm{O}_{2} \\
& \mathrm{H}_{2} \mathrm{O}_{2}+\bullet \mathrm{O}_{2}^{-} \rightarrow \bullet \mathrm{OH}+\mathrm{O}_{2}+\mathrm{OH}^{-} \\
& \mathrm{H}_{2} \mathrm{O}_{2}+\mathrm{h} v \rightarrow 2 \bullet \mathrm{OH}
\end{aligned}
$$

\section{KESIMPULAN}

1. Proses AOPs menggunakan $\mathrm{H}_{2} \mathrm{O}_{2} / \mathrm{Uv}$ Vis dari sinar matahari tidak dipengaruhi oleh konsentrasi $\mathrm{H}_{2} \mathrm{O}_{2}$, tetapi konsentrasi $\mathrm{H}_{2} \mathrm{O}_{2}$ mempengaruhi waktu kesetimbangan degradasi zat warna tartrazin dalam limbah cair mie.

2. Waktu kesetimbangan tercapai pada 30 menit dengan konsentrasi $\mathrm{H}_{2} \mathrm{O}_{2}$ $0,03 \mathrm{M}$ dan 2,5 jam untuk konsentrasi $0,02 \mathrm{M}$ dan $0,03 \mathrm{M}$ dengan penurunan tartrazin sebesar $45 \%$

3. Harga $\mathrm{pH}$ mempengaruhi proses AOPs untuk menurunkan tartrazin. Penurunan tartrazin paling besar tercapai pada $\mathrm{pH} 2$ yaitu sebesar $65 \%$.

\section{DAFTAR PUSTAKA}

Ahmad, R., 2004, Kimia Lingkungan, Penerbit Andi, Yogyakarta

Azuan, H., Abdul R.M., Lee. K.T, 2001, Solar Photocatalytic Degradation of Tartrazine using Titanium Dioxid, Jurnal Teknologi : 31-40.

Chaudhuri, M and T. Y. Wei. 2009. Decolourisation of Reactive Dyes by Modified Photo-Fenton Process Under Irradiation With Sunlight. Nature Environment and Pollution Technology An International Quarterly Scientific Journal .Vol. 8 No. 2 .pp. 359-363

Clesceri,L.S., A. E. Greenberg and A. D. Eaton.1998. Standard Methods for the Examination of Water and 
Wastewater, American Public Health Association. 20th ed. Washington, DC, USA

Hendayana S., Asep K., Aa S., Asep S., 1994, Kimia Analitik Instrumen, IKIP Semarang, Semarang.

Hudaya, T., Kartawijaya, H dan Yulia. Pengolahan Limbah Cair Warna Tekstil yang Bersifat Nonbiodegradable dalam Multi-lamp Bubble Column Photoreactor. Prosiding Seminar Nasional Teknik Kimia "Kejuangan"Pengembangan Teknologi Kimia untuk Pengolahan Sumber Daya Alam Indonesia Yogyakarta, 26 Januari 2010

Kito, M., H. Nguyen and J. Tran, 1998, Hydrogen Peroxide \& Uv Treatment, A ENVE 436 Course Project, California Polytechnic State University, San Luis Obispo

Luthfi, A., 2004, Kimia Lingkungan, Bagian Proyek Pengembangan Kurikulum, Direktorat Pendidikan Menengah Kejuruan, Direktorat Jenderal Pendidikan Dasar dan Menengah, Departemen Pendidikan Nasional.

Mahamuni, N.N and Y. G. Adewuyi. 2010. Advanced oxidation processes (AOPs) involving ultrasound for waste water treatment. Ultrasonics Sonochemistry, Volume 17, Issue 6, Pages 990-1003

Mohajerani. M, M. Mehrvar and F. EinMozaffari. 2004. An Overview Of The Integration of Advanced Oxidation Technologies and other processes for water and Wastewater treatment. International Journal of Engineering (IJE) Volume (3) : Issue (2) 120
Moutinho, ILD., Bertges, LC., and Assis, RVC., 2007, Prolonged use of the food dye tartrazine (FD\&C yellow $\mathrm{n}^{\circ} 5$ )and its effects on the gastric mucosa of Wistar rats, Braz. $J$. Biol., 67(1): 141-145.

Munter, R. 2001. Advanced Oxidation Processes - Currentstatus And Prospects Proc. Estonian Acad. Sci. Chem., Vol 50. (No 2), pp 59-80

Muruganandham, $\mathrm{M}$ and $\mathrm{M}$ Swaminathan. 2006. Advanced oxidative decolourisation of Reactive Yellow 14 azo dye by $\mathrm{UV} / \mathrm{TiO}_{2}, \mathrm{UV} / \mathrm{H}_{2} \mathrm{O}_{2}, \mathrm{UV} / \mathrm{H}_{2} \mathrm{O}_{2} / \mathrm{Fe}^{2+}$ processes - a comparative study. Separation and Purification Technology. Vol 48, Issue: 3, Pages: 297-303

Nugroho, R. dan Ikbal. 2005. Pengolahan air limbah berwarna industri tekstil menggunakan AOPs. Jurnal Akuakultur Indonesi (JAI) . Vol 1, No 2, 163-172

Pesoutova. R, P. Hlavínek, J. Matysikova. 2011. Use of Advanced Oxidation Processes for Textile Wastewater Treatment. Journal of Faculty of Food Engineering Volume X, Issue 3

Preis, S., Krichevskaya, M., Terentyeva, Y., Moiseev, A. \& Kallas, J. 2000. Treatment of phenolic and aromatic amino compounds in polluted waters by photocatalytical oxidation. J. Adv.Oxid. Technol. Vol. 5. Pp 1-8.

Rohmah, N dan Sugiarto, A.T. 2008. Pengaruh $\mathrm{pH}$ dan Konsentrasi Zat Warna Pada Penguraian Zat Warna Remazol Navy Blue Scarlet dengan Teknologi AOP . Seminar Nasional Teknoin 2008 Bidang Teknik Kimia dan Tekstil. Yogyakarta, 22 November 2008 
Degradasi zat warna azo tartrazin... (Tien Setyaningtyas dan Dian Windy Dwiasi)

Shahrour, K.H., Ch. Hachem, and Karabet. F., 2008, Degradation of Dyestuff Materials by Fenton Oxidation, Part 4, Dyes and pigment, Chemistry Department, Faculty of sciences, Damascus University, Syria 